\title{
Ross v. Bernhard: The Uncertain Future of the Seventh Amendment*
}

In Ross v. Bernhard ${ }^{1}$ the Supreme Court decided that the right to a jury trial under the Seventh Amendment" extends "to those issucs in [stockholder] derivative actions as to which the corporation, if it had been suing in its own right, would have been entitled to a jury."'s The decision repudiated the traditional doctrine that shareholders have no right to a jury trial in derivative actions, ${ }^{4}$ regardless of the character of the underlying claim for relief.

Although the express holding of the case affects only stockholder derivative actions, $\overline{ }$ " the reasoning of the opinion has vast implications for the scope of the jury right under the Seventh Amendment. A leading commentator has expressed the fear that the theory and reasoning of Ross might so expand the right to jury trial as to include within it all "legal" issues in actions formerly within equity's concurrent jurisdiction. ${ }^{6}$ This Note will explore the potential reach of the Ross opinion

- The author expresses his thanks to Professor J. W. Moore of Yale Law School for suggesting this topic.

1. 396 U.S. 531 (1970).

2. "In Suits at common law, where the value in controversy shall exceed twenty dollars, the right of trial by jury shall be preserved, and no fact tried by a jury, shall be otherwise re-examined in any Court of the United States, than according to the rules of the common law." U.S. CoNST. amend. VII.

3. 396 U.S. 531, 532-33 (1970).

4. See pp. 115-16 infra.

5. As a result of Ross, stockholders and their counsel, in the conviction that juries are more sympathetic to plaintiffs than are judges, may bring an increased number of derivative suits. This will not necessarily lead to more trials since defendants may also be quite sensitive to the biases of juries and therefore more disposed to scttle beforc trial. Since Ross there has not been any apparent increase in the number of derivative suits going to trial.

The express holding in Ross may also have an impact on the question of a director's liability for mere negligence. One commentator has concluded that "the cases in which a director is adjudged liable, or compelled to settle, a derivative suit based on nothing worse than ordinary negligence do not amount to one in a hundred." Bishop, Sitting Ducks and Decoy Ducks: New Trends in the Indemnification of Corporate Direclors and Officers, 77 YALE L.J. 1078, 1101 (1968). Courts have offered a variety of reasons for refusing to hold directors liable for mere negligence. See Dyson, The Director's Liability for Negligence, 40 IND. L.J. 341 (1965). Some courts have simply construed the facts very leniently in cases where directors are alleged to have violated the duty of care. Id. at 373-75. Now that a jury is available in stockholder derivative actions, this arca of corporate law may grow substantially, since many ultimately successful stockholder suits may be induced by the expectation of plaintiffs that juries will find directors liable for mere negligence where judges would have found no liability.

6. J. Moore, Federal Pragtice Rules Pamphlet 810-11 (1971). See note 46 infra. 
and suggest a different, less rigid means for dealing with the issue of jury trials in civil actions.

I.

The Seventh Amendment provides in part that "in Suits at common law, where the value in controversy shall exceed twenty dollars, the right of trial by jury shall be preserved ...." Prior to Ross this language was interpreted to mean that the jury trial right was preserved as it existed at common law $^{8}$ in England ${ }^{9}$ in 1791,10 the year the amendment was adopted. Since the amendinent speaks only of suits at common law, it was construed before Ross to have no application to suits in equity. ${ }^{11}$ Under the English practice prevailing in 1791, common law actions, with a few exceptions, ${ }^{12}$ were tried to a jury and suits in equity were tried to the court unless the chancellor in his discretion impaneled an advisory jury. ${ }^{13}$ Hence prior to Ross the Seventh Amendment was interpreted as adopting the English practice and so preserving the right of jury trial only in common law actions in which such a right existed in 1791.

As for rights and remedies created since 1791, the traditional case law indicated that "the right of action should be analogized to its historical counterpart, at law or in equity, for the purpose of determining whether there is a right of jury trial," unless Congress had expressly prescribed the mode of trial. ${ }^{14}$ Thus under this view trial by jury would exist as of right only if the proper analogue of a newly created cause of action were a common law action for which jury trial was provided in 1791.

7. U.S. CoNST. amend. VII. Thus the amendment does not create the jury right. 5 J. MOORE, Federal Practice I 38.08, at 85 (2d ed. 1971) [hercinafter cited as Moone's Federal Practice].

8. Parsons v. Bedford, 28 U.S. (3 Pet.) 433, 446-47 (1830).

9. Slocum v. New York Life Ins. Co., 228 U.S. 364, 377-78 (1913); United States v. Wonson, 28 F. Cas. 745, 750 (No. 16,750) (C.C.D. Mass. 1812).

10. Baltimore \& Carolina Line, Inc. v. Redman, 295 U.S. 654, 657 (1935); Dimick v. Schiedt, 293 U.S. 474, 476 (1935); F. JAMEs, Civil Procedure 337 (1965); 5 Mloone's Fenerai Practice If 38.08[5], at 79 .

11. United States v. Louisiana, 339 U.S. 699 (1950); Yakus v. United States, 321 U.S. 414, 447 (1944); Shields v. Thomas, 59 U.S. (18 How.) 253, 262 (1855). Nor has the amendment been treated as applying to suits in admiralty, Crowell v. Benson, 28J US. 22, 45 (1932), or to administrative proceedings, NLRB v. Jones \& Laughlin Steel Corp., 301 U.S. 1 (1937).

12. Examples of such exceptions were suits against the sovercign, contempt and habens corpus proceedings, and condemnation actions invoking the power of eminent domain. 5 Moore's Federal Practice I 38.08[5], at 86.

13. F. JAMEs, supra note 10, at 338 .

14. Luria v. United States, 231 U.S. 9, $27-28$ (1913); 5 Moore's Fenerall Practice 138.11 [7], at 128.4; F. JAMES, supra note 10, at 339. See also Note, The Right to a Jury Trial in a Stockholder's Derivative Action, 74 YALE L.J. 725, 727 n.I4 (1965). 
Prior to 1938, federal civil courts had a law side and an equity side, each with its own distinct procedures. ${ }^{15}$ Causes of action analogous to English common law actions were brought on the law side. Since those common law actions for which jury trial was not provided in 1791 were few, jury trial was generally available on this side of the court. Actions analogous to English equity actions were brought on the equity side of the civil courts, and jury trial was not provided.10 But with the union of law and equity in 1938, the equity and law sides of the court were merged into a single civil jurisdiction with uniform rules of procedure. ${ }^{17}$ Pursuant to these rules legal and equitable claims, formerly brought as separate causes of action on the law side and the equity side, respectively, could properly be joined in a single civil action. ${ }^{18}$

This feature of merger made the Seventh Amendment historical test extremely difficult to apply when, under the broad provisions of the Federal Rules for joinder of claims, ${ }^{10}$ equitable and legal remedies were sought alternatively or cumulatively; or when, under the Rules' provisions for compulsory and permissive counterclaims, ${ }^{20}$ legal counterclaims were made to equitable claims or equitable counterclaims to legal claims.21 In such situations, "issues formerly equitable are for the court; issues formerly legal are normally for the jury if timely demand is made." 22 The sequence in which these issues are tried, however, has great importance. For if the equitable and legal issues arise out of the same transaction or occurrence, adjudicating the equitable issues first may operate through collateral estoppel to pre-

15. 5 Moore's Federal Practice ff 38.03, at 24 .

16. Id., I 39.07, at 712-13.

17. FED. R. CIV. P. I, 2.

18. Prior to the Federal Rules equitable and legal claims could appear in the sane action, but only to a very limited extent. The Law and Equity Act of 1915, $\Lambda$ ct of March 3, 1915, ch. 90, $\$ 274$ (b), 38 Stat. 956, permitted equitable defenses or counter. claims to be interposed in an action at law, but it did not provide for the interposition of legal counterclaims in equity suits nor for the joinder of legal and equitable catises of action. See 5 Moore's Federal Practice I 38.13, at 143.44. Under Federal Rule 13, legal counterclaims can now be interposed in actions which prior to merger would have been suits in equity, and if the counterclaim arises out of the same transaction as the original cause of action it may be considered a compulsory counterclaim and its inter. position required. FED. R. CIv. P. 13(a). Rule 18 permits a party to join as many clains, "legal, equitable, or maritime," as he has against the defendant. FED. R. Civ. 1. 18(a). Though the rule is permissive, and failure to join a claim does not bar its assertion in another action, if the second claim is really a part of the first cause of action the rule against splitting a single cause of action will prohibit suit on the second claim. $3 \Lambda$ Moore's Federal Practice If $18.04[1]$, at 1852.

19. FED. R. CIV. P. 18.

20. FED. R. CIV. P. 13.

21. 5 Moore's Federal Practice 9 38.11[1], at 112; F. JAMEs, supra note 10, at 348.49.

22. 5 Moore's Federal Practice I 38.15 , at 152. 
vent a jury trial of the legal issues. The solution endorsed by the Supreme Court is that in such situations the legal issues must be tried first, even if they are merely incidental to the equitable issues. ${ }^{2 s}$

\section{II.}

In most respects Ross was a typical stockholder derivative suit. The plaintiffs, stockholders in a closed-end investment company, brought suit on behalf of the corporation against its directors and investment brokers claiming damages for injury sustained due to the payment of allegedly excessive brokerage commissions. ${ }^{24}$ But Ross was atypical in that plaintiffs demanded a trial by jury. ${ }^{25}$ Had the Supreme Court been willing to apply standard Seventh Amendment doctrine, it presumably would have held that plaintiffs had no right to a jury trial. Although the stockholder derivative suit did not exist in England in 1791 either at common law or in equity, equitable analogues to it existed at that time. ${ }^{20}$ Moreover, when the action came into being in England and the United States in the nineteenth century, it emerged

23. Beacon Theatres, Inc. v. Westover, 359 U.S. 500 (1959); Dairy Qucen, Inc. v. Wood, 369 U.S. 469 (1962).

24. Plaintiffs were stockholders of Lehman Corporation. They alleged that Ichman Brothers controlled the corporation through an illegally lange representation on its board of directors, in violation of the Investment Company Act of 1940, 15 U.S.C. \$\$ 80 (a)(1) - (b)(21) (1970). The plaintiffs further alleged that the corporation, under the control of Lehman Brothers, had paid excessive brokerage commissions to Lchman Brothers, and that the payments of these fees constituted a conversion of the corporation's assets as well as a "gross abuse of trust, gross misconduct, willful misfeasance, bad faith, gross negligence." Finally it was charged that both the individual defendants and Lehman Brothers had breached their fiduciary duties to the corporation and that the payments of the brokerage commissions amounted to a waste and spoliation of the corporation's assets. Plaintiffs prayed for a judgment requiring the defendants "to account for and pay to the corporation for their profits and gains and its losses." Bricf for Petitioners at A25-A27, Ross v. Bernhard, 396 U.S. 531 (1970).

25. Brief for Petitioners at A20, Ross v. Bernhard, 396 U.S. 531 (1970). Defendants' motion to strike this demand was denied. The district court cited Del'into $v$. Provident Security Life Ins. Co., 323 F.2d 826 (9th Cir. 1963) cert. denied, 370 U.S. 950 (1904), for the proposition that "although the aid of equity is needed in order to establish the stockholders' right to sue on behalf of the corporation, the claim is that of the corporation and the right to a jury trial is to be judged as though the corporation werc suing." Ross v. Bemhard, 275 F. Supp. 569, 570 (S.D.N.Y. 1967). Finding that there vere "substantial grounds for difference of opinion" as to the jury question, and that "an immediate appeal would materially advance the ultimate termination of this litigation," the district court permitted an interlocutory appeal pursuant to 28 US.C. $\$ 1292(\mathrm{~b})$ (1970). Ross v. Bernhard 65 Civ. 665 (S.D.N.Y., Dec. 6, 1967), cited in Brief for Pectitioners at AJI, Ross v. Bernhard, 396 U.S. 531 (1970). The court of appeals resersed, holding that a stockholder derivative suit "has always been treated as one, unitany action broughi at equity" and that therefore the Seventh Amendment does not extend the jury right to it. Ross v. Bernhard, 403 F.2d 909, 914 (2d Cir. 1968). The court specifically disagreed with DePinto. Id. at 911 . Because of this disagreement among the cireuits, the Supreme Court granted certiorari. 394 U.S. 917 (1969).

26. Prunty, The Shareholder's Derivative Suit: Notes on its Derivation, 32 N.Y.U.I. REV. $980-85$ (1957). 
as a wholly equitable action. ${ }^{27}$ From its inception until Ross, the stockholder derivative suit had always been viewed, with one excep. tion, ${ }^{28}$ as a single cause of action in equity ${ }^{20}$ excluded from the purview of the Seventh Amendment's jury trial guarantee..$^{30}$

Instead of applying the traditional historical test to the stockholder derivative suit and denying the jury trial request, the Supreme Court in Ross held that there was a right to trial by jury. Whereas prior courts had seen the derivative suit as a single cause of action in equity, the Court refused to view the suit as a unitary action. Rather, stressing the dual nature of the action- "first, the plaintiff's right to sue on behalf of the corporation and, second, the merits of the corporation's claim itself"31_it treated the derivative suit as involving the presen. tation of two separable claims. While conceding that plaintiff's claim to standing was "historically an equitable matter," 32 the Court stated that the underlying corporate claim could be legal or equitable. If equitable, no Seventh Amendment problem is presented and no jury right exists; ${ }^{33}$ but if legal, then the Court deemed relevant the teaching of the landmark cases Beacon Theatres $v$. Westover ${ }^{34}$ and Dairy

27. Note, The Right to a Jury Trial in a Stockholder's Derivative Action, 74 Yalt L.J. $725,729-32$ (1965).

28. DePinto v. Provident Security Life Ins. Co., 323 F.2d 826 (9th Cir. 1963), cert. denied, 376 U.S. 950 (1964). For an excellent critique of DePinto see Note, The IRight to a Jury Trial in a Stockholder's Derivative Action, 74 YALE L.J. 725 (1965).

29. See, e.g., Cohen v. Beneficial Loan Corp., 337 U.S. 541, 548 (1949); Dodge v. Woolsey, 59 U.S. (18 How.) 331, 341 (1855); Ross v. Bernhard, 403 F.2d 909, 912 (2d Cir. 1968); Richland v. Crandall, 259 F. Supp. 274, 279 n.8 (S.D.N.Y. 1966); Liken v. Shaffer, 64 F. Supp. 432, 441 (N.D. Iowa 1946).

30. See, e.g., Ross v. Bernhard, 396 U.S. 531, 544 \& n.4, 546 (1970) (Stewart, J., dis. senting); Ross v. Bernhard, 403 F.2d 909, 912 (2d Cir. 1968); Richland v. Crandall, 259 F. Supp. 274, 279 (S.D.N.X. 1966); Miller v. Weiant, 42 F. Supp. 761 (S.D. Ohio 1942). In states where the civil jury right is preserved by a constitutional provision similar to tlic Seventh Amendment, the majority of cases view the derivative suit as wholly cquitable and therefore not within the ambit of the constitutional guarantee. See Note, The Right to a Jury Trial in a Stockholder's Derivative Action, 74 YALE L.J. 725, 732 \& n.35.

31. 396 U.S. at 534-35.

32. Id. at 538 .

33. Id. at 535

34. 359 U.S. 500 (1959). In Beacon plaintiff sought declaratory relief and an injunction prohibiting defendant from suing for treble damages under the antitrust laws pending the outcome of the declaratory judgment litigation. Defendant asserted a compulsory counterclaim and a cross-claim, raising the issties which would have been raised in the antitrust suit for treble damages, and demanded a jury trial. The district court viewed the complaint for declaratory relief as essentially equitable, and, purporting to exercisc its discretion under FED. R. Civ. P. 42(b) and 57, decided to try to the colurt the antitrust allegations common to the complaint, compulsory counterclaim, and cross-claim. Dc. fendant, alleging deprivation of its jury right, sought a writ of mandamus to compel thic district court to allow jury trial of all common issues. The court of appeals refused the writ, 252 F.2d 864 (9th Cir. 1958), and the Supreme Court reversed, 359 U.S. 500 (1959).

On the grounds that the defendant would have been entitled to a jury trial in a treble damage suit against plaintiff, and that the Declaratory Judgment Act, 28 U.S.C. $\$ 8$ 2201-02 (1970), specifically preserves the right to jury trial for both parties, the Court held that defendant could not be deprived of that right merely because plaintiff used 
Queen, Inc. v. Wood. ${ }^{35}$ The Court appropriately cited these cases, both of which involved the presentation of historically separable legal and equitable claims in the same action, for the proposition that

where equitable and legal claims are joined in the same action, there is a right to jury trial on the legal claims which must not be infringed either by trying the legal issues as incidental to the equitable ones or by a court trial of a common issue existing between the claims. ${ }^{36}$

The application of this proposition to the derivative suit viewed as an action involving two separable claims led the Court to the conclusion that when the underlying claim in a derivative action is legal, "the right to a jury is not forfeited merely because the stockholder's right to sue must first be adjudicated as an equitable issue triable to the court." 37

Thus the right of the shareholders in Ross to have a jury trial in their derivative action was determined not by the character of their claim of standing, which was clearly equitable, but by the "nature of the issue" in the underlying corporate claim. ${ }^{38}$ If that claim involved "legal" issues, a jury right would exist. In determining whether a

the declaratory relief procedure to sue defendant first. 359 U.S. at 504. Morcover, the Court held that even assuming that the complaint did present grounds for equitable relief, it would be error, unless there was the danger of irreparable injury or the lack of an adequate legal remedy, to try the common issues first to the court, since jury trial of these issues would possibly be precluded by collateral estoppel. Id. at 508 .

35. 369 U.S. 469 (1962). The owners of the trademark "Dairy Queen" sued a trademark licensee for breach of the licensing contract. Plaintiff sought (a) temporary and permanent injunctions to restrain defendant from any use of or dealing in the franchise and trademark, (b) an accounting to determine the exact amount of money oving by defendant and a judgment for that amount, and (c) an injunction pending accounting to prevent defendant from collecting any money from franchised stores. Defendant denied breach of contract, pleaded laches and estoppel, and alleged violations of the antitust laws by plaintiffs in connection with their dealings with the trademark. In addition, defendant demanded a jury trial. Plaintiff moved to strike this demand and the district court granted the motion on the alternative grounds that either the action was "purely equitable," or that if legal issues were raised they were merely "incidental" to the equitable issues. MicCullough v. Dairy Queen, Inc., 194 F. Supp. 636, 687-88 (E.D. Pa. 1961).

In either case no right to a jury existed. Defendant sought mandamus in the court of appeals to compel the district judge to vacate this order. The court of appeals denicd this request without opinion, and the Supreme Court granted certiorari, 363 US. 874 (1961). The Court held that insofar as the complaint requested a money judgment it presented a claim which was "unquestionably legal," Dairy Queen, Inc. v. Wood, 369 U.S. 469,476 (1962), and that since the factual issues presented by this legal claim "are common with those upon which [plaintiff's] claim to equitable relief is bzed, the legal claims involved in the action must be determined prior to any final court determination of [plaintiff's] equitable claims." Id. at 479 .

36. Ross v. Bernhard, 396 U.S. 531, 537-38 (1970).

37. Id. at 539 .

38. "The Seventh Amendment question depends on the nature of the issuc to be tried rather than the character of the overall action." Id. at 538. 
particular claim is legal or equitable in nature, the Court indicated in a footnote that it would consider:

[F]irst, the pre-merger custom with reference to such questions; second, the remedy sought; and, third, the practical abilities and limitations of juries. ${ }^{30}$

The Court determined that the underlying corporate claim in Ross was "at least in part, a legal one." While never explicitly applying its tripartite test in making this determination, the Court emphasized that the claim was for money damages and involved allegations of breach of contract and gross negligence. ${ }^{40}$

Other commentators have rightly pointed out that the Court has ignored history and precedent by treating the derivative action as involving separable claims. ${ }^{41}$ This criticism will not be rehearsed here. For purposes of this Note it is enough to recognize that in Ross the Court extracted the legal issues from a formerly unitary equitable action and required that they be tried to a jury upon demand. This was not done in either Beacon or Dairy Queen. Thus Ross represents a departure from precedent and a possibly substantial extension of the Seventh Amendment jury right.

III.

To gauge the potential scope of this extension it is necessary to analyze the Court's reason for disregarding the equitable nature of the shareholders' standing claim when seeking to determine whether the shareholders had a right to a jury trial of the underlying corporate claim. The reason offered was the merger of law and equity in 1938. From the passage of the Seventh Amendment until merger, no remedy at law existed for stockholders seeking to enforce a claim of their corporation, for stockholders were without standing to assert corporate claims on the law side of the court. ${ }^{42}$ Hence such a suit had to be brought on the equity side, where jury trials were not provided as of right. ${ }^{43}$ But with merger, the Court held in Ross,

39. Id. at 538 n.10.

40. Id. at 542-43. For a full discussion of this test, see pp, 126.33 infra.

41. The Supreme Court, 1969 Term, 84 HARV. L. REv. 1, 174-76 (1970); Notc, Jury

Trial in a Stockholders' Derivative Suit, 65 Nw.U.L. REv. 697, 700.07 (1970).

42. Ross v. Bernhard, 396 U.S. 531, 534-35 (1970).

43. See p. 113 supra. 
[p] urely procedural impediments to the presentation of any issue by any party, based on the difference between law and equity, were destroyed. . . . The historical rule preventing a court of law from entertaining a shareholder's suit on behalf of the corporation is obsolete; it is no longer tenable for a district court, administering both law and equity in the same action, to deny legal remedies to a corporation, merely because the corporation's spokesmen are its shareholders rather than its directors. ... [N] othing turns now upon the form of the action or the procedural devices by which the parties happen to come before the court. ${ }^{14}$

....

... After adoption of the rules there is no longer any procedural obstacle to the assertion of legal rights before juries, however the party may have acquired standing to assert those rights. ${ }^{45}$

Under this reasoning, which will be termed the "procedural impediments" argument, no procedural obstacle now exists to the assertion of legal rights before juries. That is, legal rights which were tried without a jury in equity because of a procedural obstacle to their presentation at law must now be tried to a jury upon demand. In Ross the Court characterized law's refusal to recognize a stockholder's standing to sue derivatively as a procedural impediment to the assertion of legal rights before a jury. Since merger destroyed such obstacles and since petitioners had demanded a jury trial, the Court required that the underlying legal rights be tried to a jury.

Although the Court may have been unaware of the implications of its decision, it seems plain that the procedural impediments argument would result in the extension of the Seventh Amendment jury right to vast portions of the former equity practice. For the bulk of equity's jurisdiction was concurrent, covering "all cases of legal rights, where, under the circumstances, there was not a plain, adequate, and complete remedy at law." 40 The rights which formed the basis of the request for relief were recognized as "legal" rights usually adjudicated

44. 396 U.S. at $539-40$ (emphasis added).

45. Id. at 542 (emphasis added).

46. 1 J. STORY, EQuity JuRISprudence 117 (14th cd. 1918) (emphasis added). Among the actions falling within this broad category were suits to compel specific performance of a contract, suits for cancellation of a contract, and suits $10 \mathrm{cnjoin}$ tortious action. All of these actions, which are common today, can and usually do involve so.called "legal" issues. For example, in a damage action for breach of " $x$ " contract, the issues of whelher a contract exists, what its terms are, and whether it has been breached are tricd to the jury, assuming one has been demanded. These issues in this context are "legal." But in a suit to compel specific performance of " $x$ " contract or in a suit for cancellation, these very same issues would have been, prior to Ross, tried to the court. Similarly, in a tort action at law for damages, the issue of tortious action vel non is tricd to the jury. But in a suit to enjoin tortious action, this same issue was, before Ross, tried to the court. 
on the law side of the court, but because the remedy at law was inadequate, the claim had to be brought on the equity side where no jury trial was provided. The remedy at law was recognized as inadequate in cases within the concurrent jurisdiction because a particular remedy was sought which the court, when sitting at law, had historically refused to grant. ${ }^{47}$ Such remedies were dispensed exclusively by the equity side of the court. Thus law's refusal to grant these "equitable" remedies was an obstacle to the assertion of legal rights before juries. But it was an obstacle removed by merger, for as the Court stated in Ross:

[a]ctions are no longer brought as actions at law or suits in equity. Under the Rules there is only one action-a "civil action"-in which all claims may be joined and all remedies are available.48

Since merger created a single civil court with the power to grant all remedies formerly available on either side of the court, it nullified law's traditional refusal to grant equitable remedies for legal rights. Once this historical restraint was removed, it could no longer be an obstacle to the assertion of legal rights before juries. Hence the Court's command in Ross that legal rights must now be tried to a jury, if prior to merger procedural impediments on the law side

47. Story viewed the concurrent jurisdiction of equity as having its origin in two sources.

[E] ither the Courts of Law, although they have general jurisdiction in the matter, cannot give adequate, specific, and perfect relief; or under the actual circumstances of the case they cannot give any relief at all. The former occurs in all cases when a simple judgment for the plaintiff or for the defendant does not meet the full merits and exigencies of the case; but a variety of adjustments, limitations, and cross claims are to be introduced and finally acted on; and a decree meeting all the circumstances of the particular case between the very parties is indispensable to complete distributive justice. The latter occurs when the object sought is incapable of being accomplished by the Courts of Law; as for instance a perpetual injunction, or a preventive process to restrain trespasses, nuisances, or waste. 1d. at 117.

The impact of the procedural impediments argument upon that portion of the concur. rent jurisdiction where the remedy requested was beyond the power of the law courts is discussed in the text of this Note. For the impact of the procedural impediments argument on those situations where law had the power to grant the remedy requested but could not grant complete relief, see note 49 infra.

48. 396 U.S. at 539 (emphasis added). It might be argued that by focusing on "pro. cedural impediments," the Court was limiting its extension of the jury right to those formerly equitable cases where only standing was uniquely available in equity courts. Such a reading might contend that while remedy is "substantive," standing is "procc: dural," hence the reach of Ross is more limited than the text above suggests. But if law's refusal to grant equitable remedies is "substantive," an anomaly results, since merger, which nullified this refusal, was specifically designed not to affect "substantive" rights. See note 52 infra. It should be noted that the standard for distinguishing between "procedure" and "substance" evolved by Erie R.R. v. Tompkins, 304 U.S. 64 (1938), and its progeny is completely irrelevant here since there is no federal-state cholce of law issue. Indeed, the question whether a stockholder may sue on behalf of his corporation -which the Ross Court deemed "procedural"-is "substantive" for Erie purposes. See Swanson v. Traer, 354 U.S. 114, 116 (1957). See also Cohen v. Beneficial Loan Corp., 397 U.S. 541, 555-57 (1949). 
forced such rights into equity, is applicable to all legal rights asserted in requests for traditionally equitable remedies. ${ }^{10}$

In sum, the Court's procedural impediments reasoning requires that wherever a claim asserting legal rights was brought in equity because the remedy sought at law was inadequate, a jury trial must now be provided upon demand to adjudicate the underlying legal rights. This reasoning effectively extends the right to jury trial to all former equity actions, with the exception of those deemed to be within the exclusive jurisdiction of equity. ${ }^{50}$ Such an extension cannot be justified under the Seventh Amendment, which by its terms applies only to common law actions. 51 To attempt justification of this extension as a consequence of merger is to ignore the express intent of Congress that the institution of uniform civil rules should not expand the jury trial right. ${ }^{52}$

The procedural impediments argument reaches as far as it does because the Court has neglected the role which procedural distinctions played in the distribution of civil actions between law and equity. The Seventh Amendment reflected a compromise decision to let the existing division of cases between law and equity dictate the scope of

49. Story indicated that the concurrent jurisdiction of equity embraced more than just situations where the remedy requested was one which the law courts traditionally did not have the power to grant. See note 47 supra. The concurrent jurisdiction also extended to cases where the remedy at law was inadequate in another way. Some remedies viere dispensed both by the law courts and by equity. While the remedy was therefore available on the law side of the court, other procedural limitations peculiar to the law side rendered the remedy an incomplete form of relief failing to satisfy all the circumstances of the particular case. To avoid these procedural limitations and gain comprehensive relief, the plaintiff had to seek the desired remedy on the equity side of the court. But the procedural limitations on the ability of the court at law to perfect relicf can no longer be deemed to bar the presentation of the underlying legal issues before a jury. For merger and the uniform Federal Rules made the more flexible equity practices available to the modern civil court.

50. Story characterized equity's jurisdiction as tripartite in nature, composed of three subjurisdictions entitled the exclusive, the concurrent, and the auxiliary. J. Srons, supra note 46 , at 116. The concurrent jurisdiction has already been explained. See note 47 supra. The exclusive jurisdiction encompassed rights and interests not recognized or protected in law courts, such as those involving trusts. See 1 Aloore's Feorral PrActice: 9 0.6 [2.-2], at 216. The procedural impediments argument would appear to leave this portion of equity unaffected because in no sense could the rights involved be decmed "legal." Regardless of what remedy was requested, these rights could not be brought to the law court. The auxiliary jurisdiction was exercised when equity acted in aid of an action at law, as, for example, by way of a bill of discovery or by a creditor's bill to set aside fraudulent transfers. Id. The coming of merger and the institution of unitied rules has given the civil court access to these procedural aids regardless of whether the cause of action would formerly have been characterized as legal or equitable.

51. See p. 113 supra.

52. 28 U.S.C. $\S 2072$ (1970):

Such rules shall not abridge, enlarge or modify any substantive right and shall preserve the right of trial by jury as at common law and as declared by the Setenth Amendment to the Constitution. 
the right to jury trial in civil actions. ${ }^{53}$ Yet that division itself was based on procedural limitations self-imposed by the common law courts. With the exception of its area of exclusive jurisdiction, equity gained jurisdiction over an action only when law refused to accept jurisdiction due to a procedural self-limitation regarding such matters as standing, ${ }^{,-4}$ joinder of parties ${ }^{55}$ and claims, ${ }^{56}$ or remedy. ${ }^{57}$ By adopting the division of cases between law and equity as the basis for the jury right, the Seventh Amendment gave constitutional status to these procedural impediments, making them the touchstone of the jury right in civil actions. The Court's suggestion in Ross that merger abolished these procedural impediments would destroy the very basis of the law/equity distinction and remove the foundation of the Seventh Amendment.

The procedural impediments argument which the Court employs in Ross would, then, effectively vitiate the intent of the Seventh Amendment merely to preserve the jury right as at common law, and would extend that right to most of the former jurisdiction of equity. The fact that the opinion makes no reference to the scope of that extension may indicate that the Court was blind to the significance of its argument. On the other hand, it is conceivable that the Court knew precisely what it was doing and intended to lay the groundwork for a substantial extension of the jury trial right in the future. Mr. Justice Stewart for one, dissenting in Ross, suggested that his brethren in the majority might have an "overpowering bias in favor of jury trials in civil actions." 58

Before the Court explicitly undertakes such an extension, it should consider certain factors with which it did not concern itself in Ross. First, the extension is in no way dictated by the Seventh Amendment and would represent instead a policy decision by the Court as to the advisability of a greater use of jury trials in civil actions. Second, the procedural impediments reasoning cannot logically be limited short of extending the jury right to the entire concurrent jurisdiction of equity. The categorical nature of this extension would provide a right to jury trial for at least some cases in which a court trial might be preferable, if only because of the complexity of the issues involved. ${ }^{50}$

53. 5 Moore's Federal Practice If 38.08[5], at 68-76; Henderson, The Background of the Seventh Amendment, 80 HARv. L. REv. 289, 299 (1966).

54. Ross v. Bernhard, 396 U.S. $531,539.43$ (1970).

55. F. JAMEs, supra note 10 , at 455-56.

56. Id. at 446-50.

57. See note 47 supra.

58. 396 U.S. at 551 (1970) (Stewart, J., dissenting).

59. See J. Frank, Courts on Trial 108-45 (1950). 
Third, the breadth of the extension could significantly increase the number of jury trials in civil actions and thereby contribute to the growing backlog and delay in the federal district courts."

IV.

On the civil side-not to mention the criminal side ${ }^{01}$ - the federal district courts are grievously overburdened. The immense and growing backlog of cases ${ }^{62}$ is merely one indication that they are unable to cope efficiently with the demands placed upon them. Another index is the slow pace of justice. The median time interval ${ }^{13}$ from filing to disposition at trial of civil cases terminated during fiscal year 1970 was 17 months. For ten per cent of these cases the interval was more than 44 months. $^{64}$ To say that the pace of justice in the federal district

60. Unfortunately it is not possible to quantify the potential increase since no arailable statistics-not even those of the Administrative Office of the Urited States Courts -indicate how many civil suits in the federal district courts assert legal rights and seck equitable remedies. The statistics of the Administrative Office do break down civil cases in the federal district courts by "nature of suit." But it is a breakdown not useful for purposes of this discussion. For example, the statistics indicate how many tort actions there were in a given year, but not how many of them vere brought in the form of an injunction suit. See, e.g., ANNUAL REPORT OF THE DIRECTOR OF THE ADMINistative OFFICE of THE UNITED STATES COURTS, 1968, at 194-95, 208-10, 231-33 [hereinafter cited as AD.s. OFF. ANN. REP. preceded by the appropriate year]. And cren if there were such statistics from which the number of actions formerly falling within equity's concurrent jurisdiction could be deduced, there would nevertheless be no basis for predicting in how many of such suits a jury would actually be demanded, since there are no data indicating the frequency with which the jury trial right is now exercised. Though precise measurement cannot be made on the basis of available information, it vould seem obvious that if the right to jury trial extends, in light of Ross, to injunction suits, suits to compel specific performance, suits for cancellation of a contract, and other actions that fell within the concurrent jurisdiction of equity, there will be a substantial increase in the number of jury trials in the federal district courts.

61. See, e.g., Chief Justice Burger, The State of the Judiciary, 56 A.B.A.J. 929 (1970).

62. On the first day of fiscal 1970, i.e., July I, 1969, there viere 86,321 civil actions pending in the district courts. During fiscal $1970,87,321$ civil actions were commenced and 80,435 were terminated. Thus, by the end of the fiscal year the number of civil cases pending was 93,207 , an increase of $8.0 \%$ in one year. 1970 ADM. OFf. ANis. REP. 226. Nor was this increase very unusual. From fiscal 1965 through fiscal 1969, for example, the number of cases pending increased each year, respectively, by the following percentages: $3.0 \%, 6.3 \%, 1.0 \%, 3.2 \%, 4.7 \%$. 1965 ADM. OFF. ANN. REP. 174; 1966 ADM. OFF. ANN. REP. 166; 1967 ADM. OFF. ANN. REP. 196; 1968 AdM. OFF. ANN. REP. 190; 1969 AD3. OFF. ANN. REP. 200.

63. It should be noted that at least insofar as judicial time figures are concerned, medians tend to be slightly shorter than averages. Green, The Situation in 1959, 328 ANnals 7, 11 (1960); 1959 Adm. OfF. ANN. Rep. 101.

64. This calculation excludes land condemnation cases, habeas corpus cases, deportation reviews, and motions to vacate sentence. 1970 ADMs. OFF. ANN. REP. 245i. The figures for some districts are sobering indeed. In the Southern District of New York, where 395 cases reached trial (more than in any other district and 5.4\% of the total number of cases reaching trial), the median time interval from filing to disposition ivs 35 months and for $10 \%$ of the cases the interval was more than 61 months. Id. In the Enstern District of Pennsylvania where 378 cases (or $5.2 \%$ of the total) reached trial, the median interval was 41 months and for $10 \%$ of the cases the interval vas 71 months. Id., 245i245j. Although some commentators prefer as the measure of delay the time interval between the date when a case is "at issue" and the date when it reaches urial, sec, e.g., 
courts is too slow because half of the cases going to trial span more than a year and five months from filing to disposition, though perhaps a reasonable statement, relies essentially on intuition, since no absolute standard of judicial efficiency exists. But clearly the pace is slow in a relative sense: in 1945 the median time interval from filing to dispo. sition at trial was 9 months; ${ }^{05}$ by 1955 it had risen to 14.6 months; and by 1965 to 17 months. ${ }^{\circ 7}$

Whatever may be its merits on other grounds, the jury trial, in comparison with the court trial, contributes to the slow pace of justice, and thus operates to hinder efficient judicial administration. In fiscal 1970, for example, there were 9,449 civil trials in the federal district courts, of which 6,078 were tried to the court and 3,371 to the jury. ${ }^{08}$ The table below ${ }^{60}$ indicates the greater time required for the disposition of civil cases by jury trial:

Length of Trial
Less than 1 day
1 day
2 days
3 days
4 to 9 days
10 to 19 days
20 days and longer

$\begin{array}{cc}\begin{array}{c}\text { Pctge of } \\ \text { Jury Trials }\end{array} & \begin{array}{c}\text { Pctge of } \\ \text { Court Trials }\end{array} \\ 13.1 & 43.3 \\ 13.0 & 31.3 \\ 29.4 & 12.8 \\ 20.2 & 5.7 \\ 22.1 & 5.5 \\ 1.7 & 1.1 \\ .4 & .3\end{array}$

Of course these figures, taken alone, may be misleading because of possible differences between the types of cases tried to juries and those tried to courts. The important question is how much more time on the average would be required if a given case were tried to a jury rather than a judge. ${ }^{70}$ Although the differential is extremely diffi-

Green, supra note 63, at 9-10, the modern view appears to be that the interval from filing to disposition is a more useful measure. See Preliminary Recommendations of the Reporter, ABA Comm. on Standards of Judicial Administration (1971).

65. 1945 ADM. OFF. ANN. REP. 91.

66. 1955 ADM. OFF. ANN. REP. 178.

67. 1965 ADM. OFF. ANN. REP. 191. Since 1965 the interval has fluctuated between 17 and 19 months. 1966 ADM. OFF. ANN. REP. 185; 1967 ADM. OFF. ANN. REr. 219; 1968 ADM. OfF. ANN. REP. 216; 1969 ADM. OfF. ANN. REP. 228.

68. 1970 ADM. OFF. ANN. REP. 255. This figure includes evidentiary trials (jury and non-jury), hearings on temporary restraining orders and preliminary injunctions, hear. ings on bankruptcy review petitions, and motions in reorganization proccedings, ld. at 257.

69. The table is based on statistical material included in 1970 ADM. OFF. ANN. RE1. 255.

70. H. Zeisex, H. Kalven, JR. \& B. Buchholz, Delay in the Court 74 (1959). 
cult to calculate, ${ }^{71}$ a leading study in the field estimates that sixtyseven per cent more time would be needed.72

That jury trials, on the whole, take longer than court trials is quite understandable. Extra time is required for jury selection, voir dire, and the charge. Opening and closing statements tend to take longer when delivered to a jury. ${ }^{73}$ Judge and counsel must take far greater precautions, particularly with regard to evidence, when a jury is present, and these precautions are time-consuming. Furthermore, certain procedures, such as the motion for judgment n.o.v. and the motion to set aside the verdict as against the weight of the evidence, while unknown to courts trials, place additional demands upon the time of court and counsel in jury trials.

Thus more court time is required to dispose of a case by jury trial than by court trial. In the absence of an offsetting increase in judicial resources, ${ }^{74}$ an increase in the number of jury trials can be expected to reduce the overall efficiency of the courts by lowering the number of cases that the courts can handle in a given time period. To do this at a time when the absolute number of cases coming to trial is increasing can only contribute to the growing backlog of cases and further retard the pace of justice.

The dictates of efficient judicial administration are intimately con-

71. As Zeisel, Kalven, and Buchholz explain:

[W] are faced with a serious difficulty. To be sure, once in a long while it hap. pens that a case tried to a jury is reversed and then tried again, with the jury waived. But aside from the rarity of such an event, at the second trial the care is really not the same any more. And since it is quite unthinkable that cases could be tried experimentally twice, it becomes clear that, even with all the time and money for research, it would not be possible to solve the problem with precision. Id. at 74 .

72. Id. at 79. The authors based their study on the Supreme Court of New York County. It is not improbable that their findings are roughly applicable to the federal district courts.

73. Id. at 79 .

74. There is little reason to believe that such an increase will be provided in the foreseeable future, especially in view of the disappointing effect which appointment of more judges has had in the past. As former Senator Joseph Tydings has observed:

The size of the Federal judiciary has almost doubled since 1940 . Yet we are sinking deeper and deeper into the quagmire of congestion and delay. And the statisties disparage the suggestion that more judges alone are an answer to the problem. During fiscal 1959, more than 62,000 cases were disposed of by the Federal district courts. Two years later, in 1961, 63 additional district judgeships were created. Yet in fiscal 1964, after virtually all of those appointments had been filled, the district courts disposed of only 64,000 cases. Thus, with an increase of 25 per cent in judicial manpower, the courts were able to step up their productivity by only 3 per cent. Hearings on $\$ .915$ and H.R. 6111 Before the Subcomm. on Improvements in Judicial Machinery of the Senate Comm. on the Judiciary, 90th Cong., Ist Sess. 5 (1957). No one is quite sure why this increase in manpower has been so ineffectual. J. Frasi, Aisenucas LAw: The CASE for Radical Refordr 5-6 (1969). Antiquated administrative practices offer at least a partial explanation. Indeed, as former Chief Justice Warren has pointed out, "adding more judges to courts using outmoded methods of administration is more likely to retard production than it is to stimulate it." 44 ALI Procesoives 1, 3 (1967). 
nected with the dictates of justice, for at some point delay in the administration of justice becomes a denial of justice itself. Even assuming that in a particular case a jury may be better able than a court to reach a "just" result, ${ }^{75}$ it does not follow that increasing the number of jury trials will enhance the overall fairness of the civil judicial process. The effect of the increased delay in the disposition of cases occasioned by a significant extension of the jury right may outweigh whatever benefits the jury may contribute to the achievement of justice in particular cases.

V.

While the procedural impediments reasoning in Ross portends a substantial extension of the jury right which would exacerbate the problems of backlog and delay in the federal district courts, that reasoning is employed in the opinion only to justify the Court's disregard of the equitable nature of the shareholder's standing claim. The Court then examines the underlying corporate claim, both as to the rights asserted and the remedy sought, to determine whether the jury right attaches under the Seventh Amendment. ${ }^{76}$ In making this examination the Court ignores an earlier footnote in the opinion which would appear to govern the inquiry. ${ }^{77}$ In that footnote the Court specified a tripartite "nature of the issue" test to determine the "legal" nature of an issue and so the incidence of the jury right. This

75. No purpose would be served by here recounting the arguments for and against civil juries. See, e.g., J. Frank, Courts on TrLAL 108-45 (1950); J. Frank, LAW aNd THIE MOdEHN Mind 170-85, 302-09 (1935); H. Janes, Crisis in The Courts 191-205; G. Joiner, Civil Justice and tue JuRy (1962); D. KarLen, Judicial Administration: TIIE AMEkican IEXPERIENCE 66 (1970); Kalven, The Dignity of the Civil Jury, 50 VA. L. REv. 1055 (1964); Sunderland, The Inefficiency of the American Jury, 13 MICII. L. REv. 302 (1915). As two leading commentators on this subject point out, "Most of the unrest over the jury today is limited to its use in civil trials. It is agreed that the case for the jury in criminal trials is different and much stronger." H. KALveN, JR. \& H. ZEISEL, THE AMERICAN JURY 9 (1966). It is noteworthy that in England there has been a "steady decline" in the num. ber of trials by jury. In 1969 the jury was used in only $2.27 \%$ of the total number of civil actions tried in London and only $0.17 \%$ of those tried on $\Lambda$ ssizc. 1969 JUdicint Statistics, ENGLANd and Wales: Civit. Judicial Sratistics 13. Although there is no coil. sensus on the issue of jury trial in civil actions and although the debate is "threaded with difficult value judgments," KALVEN AND ZEISEL, supra at 9, it would secin clear that there are at least some - and probably many_cases in which, due to the complexity of the issues involved, a jury is simply not as well-equipped as a judge to administer justicc. This is particularly true of cases in the commercial field, such as stockholder derivative actions. See Ross v. Bernhard, 396 U.S. 531, 545 n.5 (1970) (Stewart, J., dissenting).

76. See p. 118 supra. On the facts of Ross, both the rights asserted and remedy sought were historically legal. If Ross were confined to its facts, the resultant extension of the jury right would not reach the whole of equity's concurrent jurisdiction. The impact of Ross on courts' efficiency would of course be correspondingly smaller. But it is difficult to find in the procedural impediments reasoning a logical way of confining Ross to its facts. See note 48 supra.

77. See p. 118 supra. 
test, purporting to be merely a restatement of the traditional Seventh Amendment historical test, is in fact a departure from it. But if given constitutional status in subsequent opinions, it could serve as a limit upon the reach of the procedural impediments argument in Ross.

The first criterion of the Court's tripartite test requires consideration of "the pre-merger custom with reference to such questions." 88 The Court fails, however, to specify what "questions" it means. In Ross, for example, the Court could have viewed the stockholder derivative suit as a unitary action, treated by pre-merger custom as equitable in nature. ${ }^{79}$ But instead it focused on the underlying corporate claim and found "pre-merger custom" to have treated that "question" as legal..$^{80}$ There is nothing in the criterion itself to prevent the Court from considering the relevant "question" in an action formerly within equity's concurrent jurisdiction to be the substantive legal rights involved, while ignoring completely the equitable character of the remedy requested. Thus whether this first criterion limits the reach of the procedural impediments argument will depend upon how the Court subsequently defines the "question" to which premerger custom is relevant.

The second criterion employed in the test is the "remedy sought." 81 Its relevance to the procedural impediments reasoning is that it ostensibly offers remedy as a limiting principle. Inclusion of the second criterion appears to mean that an underlying claim will not be viewed apart from, but rather in light of, the remedy it requests. Presumably, if the remedy sought is "legal," the underlying claim will be viewed as legal; and if the remedy sought is "equitable," the underlying claim will be viewed as equitable. The application of this criterion would thus seem to prevent extension of the jury trial right to all cases traditionally within the concurrent jurisdiction of equity, since within this jurisdiction the remedies sought were "equitable." 82

But, for at least three reasons, the inclusion of remedy sought as part of the Court's test offers no guarantee that the jury right will not be extended to the concurrent jurisdiction of equity. As previously indicated the procedural impediments argument reaches both obstacles to standing, as held in Ross, and limitations upon the remedial

78. See p. 118 supra.

79. See pp. 115-16 supra.

80. See pp. 116-18 supra.

81. See p. 118 supra.

82. See pp. 119-20 supra. The second criterion would not, however, preclude the extension of the jury right involved in Ross itsclf. See note 70 supra. 
power of the court while sitting at law ${ }^{83}$ Both are limitations on the presentation of legal issues before juries, "procedural impediments" deemed abolished by merger. To distinguish between them, and continue to give effect to remedy limitations as a bar to jury trial of legal issues while denying such effect to standing restraints, is to make an arbitrary distinction unsupported by, and indeed incompatible with, the logic of the procedural impediments argument. Secondly, the determination of what is or is not an equitable or legal remedy can be made validly only by reference to history, since the distinction between law and equity is solely historical in origin. ${ }^{84}$ Yet the Court has shown itself quite prepared to ignore the historical classification of remedies as legal or equitable. In Dairy Queen the Court disregarded the traditional characterization of an accounting as an equitable remedy, and treated it rather as a legal claim for money damages. ${ }^{85}$ Once history is disregarded in this fashion, the purported distinction between legal and equitable remedies becomes a cover for unpredictable discretion, with courts left free to classify remedies as they see fit. Finally, in light of the fact that Ross's tripartite test offers no indication as to how its three criteria are to be weighted and applied, the criterion of remedy sought may simply be ignored without violating the test. Indeed, the Tenth Circuit, relying on Ross, has already ignored remedy for purposes of determining whether an underlying claim was to be accorded a jury trial. ${ }^{80}$

The third criterion of the Ross test, the "practical abilities and limitations of juries," 87 might also serve to limit the extension of the jury right suggested by the procedural impediments argument. Its operation can be seen best by examining the way the Court could have used this criterion in Katchen $v$. Landy ${ }^{88}$ to deny the jury trial right in a clearly legal action. In that case, a bankruptcy trustee asserted and proved voidable preferences in response to a claim filed by the creditor who received the preferences. The issue before the Court was whether the bankruptcy court had summary jurisdiction to order the surrender of the preferences without a jury trial, or whether in order to preserve

83. See pp. 118-21 supra.

84. See pp. 121-22 supra.

85. 369 U.S. at $477-79$ (1962).

86. Bruce v. Bohanon, 436 F.2d 733 (10th Cir. 1970). Plaintiff sought inter alia relief in the form of an accounting. Assuming the remedy sought to be equitable, the court nevertheless declared that "we must look beyond the relicf sought and determine the true nature of the underlying claim upon which the prayer for relief is itself predicated." Id. at 736. The court concluded that the underlying claim was legal because it sounded in tort and that therefore the jury right attached. $I d$.

87. See p. 118 supra.

88. 382 U.S. 323 (1966). 
the creditor's jury right the court was required to stay its own proceedings and instruct the bankruptcy trustee to recover the preferences by instituting a plenary suit, in which a jury trial would be available to the creditor. While expressly recognizing that an action to recover a voidable preference is essentially a legal claim for debt, the Court held that the issue could be tried by the bankruptcy court without a jury. ${ }^{88}$ The reason offered for this result was that to require a plenary recovery action would be to dismember "a specific statutory scheme contemplating the prompt trial of a disputed claim without the intervention of a jury."00

Under either the traditional historical test or the first two criteria of the Ross test, the recovery action would have been found legal in nature and a jury right accorded. Neither test would have provided any justification for the Court's disregarding this result in the interest of a congressional scheme for prompt disposition of certain kinds of claims. Yet the third criterion of the Ross test, injecting considerations of the practical limitations of juries, could provide a constitutional basis for the Court's deference to the congressional scheme. Similarly, this criterion might serve as a rationale for limiting an extension of the jury right under the procedural impediments reasoning if that extension were in conflict with a congressional preference for a court trial, expressed in a statutory scheme precluding jury trials. In addition, criterion three would permit a court to deny a jury request if an action were thought to be too complex for a jury, even though the procedural impediments argument might require a contrary result.

But this third criterion at best affords an uncertain limit upon the reach of the procedural impediments argument. In the first place, it is unclear whether the criterion would be applied to situations where Congress has withdrawn a certain kind of case from disposition by jury trial much less to cases where the issues appear to be too complex for civil juries. Secondly, the Court's opinion, by failing to indicate how the three criteria in the Ross test are to be weighted and applied, would permit the third criterion to be ignored. In fact this appears to have occurred in Ross itself, for in analyzing the "nature of the issue" presented by the underlying corporate claim the Court makes no reference to the competence of juries to handle such claims.11 This failure to employ the third criterion in the actual determination of the jury right in Ross is significant, since the Court rested its opinion squarely

89. Id. at $335-38$.

90. Id. at 339 .

91. See p. 118 supra. 
on the Seventh Amendment.02 Employing the third criterion in this determination would thus have given it constitutional status. Yet the considerations reflected in the third criterion have never been a part of the historical Seventh Amendment test. The jury right preserved by that amendment was the right that historically existed at English common law in 1791.93 The fact that under English practice a particular kind of action was within the jurisdiction of the common law courts, as opposed to the equity courts, and thus generally was accorded the jury right was not the product of a rational judgment as to the "practical abilities and limitations of juries." 04 Rather it was largely a product of the power struggle between the equity chancellor and the common law courts. ${ }^{95}$ The distribution was rarely "rational" in the sense of actions being assigned according to their relative amenability to decision by juries as opposed to judges. ${ }^{00}$ The failure of the Court in Ross to employ the third criterion in its determination that the Seventh Amendment extended to the derivative action, coupled with the fact that historically the Seventh Amendment has not been viewed as embracing the considerations reflected in the criterion, raises some question as to whether the criterion can be accorded constitutional status and used to limit the reach of the procedural impediments argument.

VI.

Should the Court desire to limit the extension of the jury right which appears to be mandated by the procedural impediments argument, the criteria of the tripartite test could be employed as limiting principles. The first two criteria can be read to approximate the traditional Seventh Amendment test and contain the jury right largely within its current limits. ${ }^{97}$ And if the Court should still desire incrementally to extend the jury right to those kinds of cases where jury trial can improve the fact-finding capability of the judicial process, it could justify its extension by employing the third criterion. Before making such an extension, however, the Court should balance the benefits to be anticipated against the potential harm to the efficient dispensation of justice in the federal courts. ${ }^{98}$

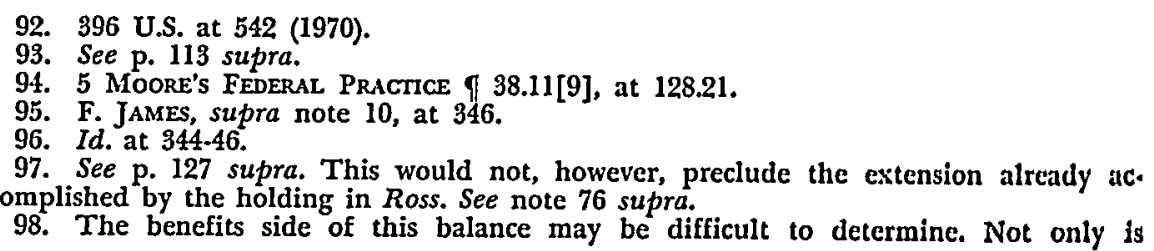


To use this approach, the Court would have to constitutionalize its tripartite Ross test and in particular its final criterion. The Court would thereby inject new considerations into the Seventh Amendment, contrary to the long-standing interpretation of the amendment as having embodied only historical distinctions. ${ }^{90}$ Thus an act of judicial Iegislation would be required.

This situation could be avoided by the Court's adoption of a nonconstitutional means to extend the jury right. An example of the non-constitutional approach can be found in Byrd v. Blue Ridge Rural Electric Cooperative, Inc. ${ }^{100}$

Byrd was a negligence action brought in federal district court, with jurisdiction founded on diversity of citizenship. One of the affirmative defenses raised was that under South Carolina's workmen's compensation act plaintiff was defendant's employee and was therefore barred from suing him because plaintiff was obliged to accept statutory compensation benefits as the exclusive remedy for his injuries. One of the questions before the Court was whether on remand the factual issues raised by this defense were to be decided by the judge or by the jury. The policy of the South Carolina courts was that such issues were for the judge. ${ }^{101}$

The Court held that for purposes of applying the doctrine of Erie R.R. v. Tompkins ${ }^{102}$ the state rule was one "of form and mode."103 But it acknowledged that the cases following Erie evinced the broader policy that federal courts should conform as nearly as possible to state rules even of form and mode when the non-application of the state rule would affect the outcome of the litigation and conceded that in the instant case the outcome might be "substantially affected by whether the issue . . . is decided by a judge or a jury."10

The Court nevertheless held that the issue must be tried to the jury because of "affirmative countervailing considerations." 105 As Mr. Justice Brennan, writing for the majority, put it,

[a]n essential characteristic [of the federal judicial system] is the manner in which, in civil common-law actions, it distributes trial

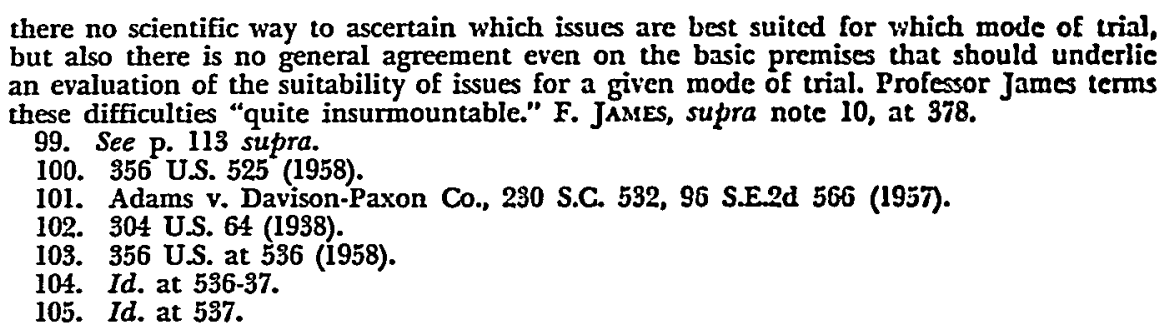


functions between judge and jury and, under the influence-if not the command-of the Seventh Amendment, assigns the decisions of disputed questions of fact to the jury. The policy of uniform enforcement of state-created rights and obligations . . . cannot in every case exact compliance with a state rule ... which disrupts the federal system of allocating functions between judge and jury....

We think that in the circumstances of this case the federal court should not follow the state rule.100

Thus the Court extended the jury right to the issue of the employment status of the plaintiff in the face of a contrary state practice which, under normal Erie principles, would govern. Justice Brennan scrupu* lously avoided resting this holding on the Seventh Amendment.107 Instead, the Byrd decision gives effect to the interest of the federal system in allocating the functions between judge and jury in accordance with its own conception of the sound administration of justice. ${ }^{108}$

Thus Byrd would serve as precedent for the extension of the jury right where the contributions of the jury to the fact-finding process were deemed to advance the sound administration of justice. The main advantage of using this non-constitutional approach is its rendy availability. To employ a constitutional approach under the Ross tripartite test, the Court would have to read its final criterion into the Seventh Amendment. Byrd offers the Court a means of avoiding such explicit judicial legislation. In addition, this approach offers

106. Id. at 537-38 (citations omitted).

107. Id. at 537 n.10.

108. A similar non-constitutional approach was employed in Fitzgerald, public Ad. ministrator v. United States Lines Co., 374 U.S. 16 (1963). There plaintiff, a scaman, claimed damages for injuries sustained while working on defendant's ship. Plaintiff brought a negligence claim against defendant under the Jones Act, which provides plaintiffs a jury trial as of right. Joined with the negligence issue were unscaworthiness and maintenance and cure claims, traditional admiralty claims which in the absence of a statute do not ordinarily require trial by jury. Plaintiff nevertheless demanded a jury trial of all the claims in his complaint. Without resorting to the Seventh Amendment the Court held that "a maintenance and cure claim joined with a Jones Act claim must be submitted to the jury when both arise out of one set of facts." Id. at 21. The Court's reasoning was firmly based on considerations of sound judicial administration. Mr. Justice Black, writing for the Court, reasoned that to require a plaintiff to submit part of his lawsuit to a judge and part to a jury complicates the trial, creates diffictilties in applying collateral estoppel and res judicata, and can casily result in excessive or in. adequate recovery. Id. at 18-20. The Court reasoned that although the Scventh Amend. ment does not require jury trials in admiralty cases, there is no basis cither in the Constitution or the Amendments to forbid them. Recognizing the Court's own responsi. bility for fashioning the controlling rules of admiralty law, Justice Black wrote:

Where as here, a particular mode of trial being used by many judges is so cumber. some, confusing, and time consuming that it places completely unnecessary obstacles in the paths of litigants seeking justice in our courts, we should not and do not hesitate to take action to correct the situation. Id. at 21 . 
greater flexibility. Since the standard is sound judicial administration, the Court may with relative ease contract an extension of the jury right should juries prove incapable of dealing with the particular kind of case in question or should the courts become so overburdened as a consequence of jury right extensions as to be unable to meet even present standards of judicial efficiency. By rooting such extensions in the Seventh Amendment, the Court in effect would grant subsequent litigants a constitutional right to a jury trial in cases to which its extensions apply. The Court can be expected to be unwilling to retrench on a constitutional right in the name of considerations of mere administrative efficiency should juries prove inept or courts become overloaded. Although it cannot be pretended that constitutional rights can never be abrogated or circumscribed, nor that rights extended on a non-constitutional basis can be retracted with complete ease, it should be clear that the non-constitutional approach does afford a relatively greater degree of flexibility.

If the inclusion of the third criterion in the Ross test indicates a desire on the part of the Court to expand the jury trial right in keeping with pragmatic considerations of juries' competence, the Court should employ the non-constitutional approach introduced in Byrd to make such extensions. This approach avoids the judicial legislation that would be required to read efficiency considerations into the Seventh Amendment and in addition leaves the Court free to retract its extensions of the jury trial right should their effect on the judicial process prove to be adverse. 